http://jurnaltarbiyah.uinsu.ac.id/index.php/raudhah e-mail: jurnalraudhah@uinsu.ac.id

p-ISSN: 2338-2163

e-ISSN: $2716-2435$

\title{
Implementasi Model Pembelajaran Sentra Dalam Mengembangkan Multiple Intellegensi Anak Usia Dini di RA Azzahra Lampung Timur
}

\author{
${ }^{1}$ Sefriyanti \\ Universitas Islam Negeri Sunan Kalijaga Yogyakarta \\ email:sefriyanti360@gmail.com \\ ${ }^{2}$ Raden Rachmy Diana \\ Universitas Islam Negeri Sunan Kalijaga Yogyakarta \\ Email: raden.diana@uin-suka.ac.id
}

Article received : 20 Agustus 2021

Article accepted : 11 Oktober 2021
Review process : 20 September 2021

Article published : 01 Desember 2021

\begin{abstract}
Abstrak
Model Pembelajaran Sentra merupakan pendekatan pembelajaran yang berpusat pada anak dan pembelajarannya dilakukan di dalam lingkaran ( Circle Time) dan sentra. Di dalam sentra bermain anak akan mengeksplor kemampuan dirinya sesuai minat dan bakat sehingga mampu menstimulasi seluruh aspek kecerdasan anak ( multiple intellegensi) melalui bermain yang terarah. Penelitian ini bertujuan untuk mengetahui apakah model pembelajaran sentra mampu mengembangkan multiple intellegensi anak di RA Azzahra Lampung Timur. Subyek penelitian ini ini terdiri dari Kepala Sekolah, Guru sentra kelompok B dan Anak didik yang berjumlah 15 anak. Teknik pengumpulan data menggunakan observasi, melalui data kegiatan anak dan ruang sentra yang ada, wawancara dan dokumentasi. Analisis data menggunakan model Miles Huberman terdiri atas mereduksi data, penyajian data dan penarik kesimpulan. Sentra yang diterapkan di RA Azzahra diantaranya; sentra persiapan, sentra seni, sentra balok, sentra bahan alam, dan sentra bermain peran. Hasil penelitian menunjukkan bahwa implementasi model pembelajaran sentra di RA Azzahra Lampung Timur untuk mengembangkan multiple intellegensi anak mampu terlaksana dengan baik melalui beberapa tahapan yang meliputi perencanaan, pelaksanaan, dan evaluasi. Kegiatan pembelajaran tersusun secara sistematis dan terencana sesuai dengan kurikulum dan standart Tingkat Pencapaian Perkembangan Anak (STPPA) usia 5-6 tahun.
\end{abstract}

Kata kunci: model pembelajaran sentra, multiple intellegence, anak usia dini

\begin{abstract}
This study aims to determine the kinesthetic intelligence, gross motor development, and the relationship between kinesthetic intelligence and gross motor development of children aged 5-6 years at RA Karya Panda Budi. This research is a correlational quantitative research. The sample in this study were 30 people. The research instrument used a questionnaire sheet. The data analysis technique in this research is to test the correlation hypothesis using the product moment formula. This research proves that: (1) as many as 10 children 5-6 years at RA Karya Panca Budi have low category kinesthetic intelligence, 16 people are in the medium category and 4 people are in the high category; (2) as many as 5 children 5-6 years at RA Karya Panca Budi had gross motor development starting to develop, as many as 18 people were developing according to expectations, and as many as 7 people were categorized as very well developed; and (3) there is a significant relationship between kinesthetic intelligence and gross motor development of children aged 5-6
\end{abstract}


http://jurnaltarbiyah.uinsu.ac.id/index.php/raudhah

e-mail: jurnalraudhah@uinsu.ac.id

p-ISSN: 2338-2163

e-ISSN: $2716-2435$

years in RA Karya Panca Budi.

Keywords: early childhood; kinesthetic intelligence; gross motor development

\section{A. PENDAHULUAN}

Pendidikan Anak usia dini merupakan pendidikan yang sangat fundamental, karena dimasa keemasan (Golden Age) anak harus mendapatkan stimulasi perkembangan yang maksimal yang mampu mengembangkan seluruh potensi yang dimiliki sehingga semua aspek perkembangan anak mampu berkembang dengan baik, karena masa usia dini adalah masa identifikasi/ imitasi, eksplorasi, masa peka dan masa bermain (Ali Rochmad Noor, 2015). Dalam mengembangkan semua aspek perkembangan anak dengan baik diperlukan proses pembelajaran yang tepat.

Proses belajar anak usia dini merupakan interaksi antara guru, teman, atau orang dewasa lainnya dalam suatu lingkungan untuk mencapai tugas perkembangannya. Interaksi yang dibangun tersebut merupakan salah satu faktor yang mempengaruhi keberhasilan dalam tujuan pembelajaran yang ingin dicapai, karena dengan proses interaksi anak akan mendapatkan pengalaman yang bermakna sehingga proses belajar mampu berjalan dengan baik (Akbar, 2020) . Untuk membantu anak dalam mengembangkan seluruh potensinya maka dibutuhkan suatu model pembelajaran yang sesuai dan memungkinkan anak berinteraksi dengan lingkungannya.

Model pembelajaran ialah suatu pola atau rancangan, penciptaan suatu lingkungan yang memungkinkan terciptanya interaksi anak yang disusun secara sistematis untuk mencapai proses pembelajaran sehingga dapat terjadi perubahan dan perkembangan . Unsur- unsur pada model pembelajaran terdiri dari : konsep, prosedur, tujuan pembelajaran, metode,materi, sumber belajar, standar kompetensi dan kompetensi dasar, teknik dan evaluasi (Fatmawati, 2019). Oleh karena itu sebagai guru harus mampu menentukan model pembelajaran yang tepat, yang akan menjadi penentu keberhasilan pembelajaran. Model pembelajaran sentra salah satu model pembelajaran yang mampu menstimulasi seluruh aspek perkembangan anak melalui bermain dengan terarah.

Model pembelajaran sentra merupakan pendekatan pembelajaran yang berpusat pada anak dan pembelajarannya dilakukan di dalam lingkaran ( Circle Time) dan sentra bermain (Mutiah, 2012), penyelenggaraan dalam pembelajarannya perpaduan antara teori dan pengalaman praktik (Mandasari, 2013). Sentra bermain adalah zona atau area bermain yang didalamnya anak akan mengeksplor dan mengekspresikan kemampuan dirinya dengan dilengkapi seperangkat alat main yang berfungsi sebagai pijakan lingkungan yang diperlukan dalam berbagai aspek untuk mengembangkan seluruh potensi dasar sesuai tahap perkembangannya dengan seimbang dan maksimal (Mulyani, 2018). Ada empat jenis pijakan main (scaffolding) di dalam sentra yaitu pijakan sebelum main, pijakan lingkungan main, pijakan saat main dan pijakan setelah main 
http://jurnaltarbiyah.uinsu.ac.id/index.php/raudhah

(Setyowati, 2019). Hal yang sangat mendasar dalam pelaksanaan model pembelajaran Sentra ini ialah : intensitas bermain dan densitas bermain. Intensitas bermain adalah waktu yang dibutuhkan untuk mendapatkan pengalaman proses bermain anak dalam tiga jenis main, sedangkan densitas bermain adalah keragaman jenis main yang disediakan untuk mendukung pengalaman dalam proses bermain anak (Fitria et al., 2020). Tiga jenis main dalam pembelajaran sentra diantaranya (a) Sensorimotor atau fungsional, (b) Bermain peran, (c) Bermain pembangunan (Lailan, 2017).

Model pembelajaran berbasis sentra di konsep atas dasar keunikan anak, mengadaptasikan perbedaan dalam belajar dengan minat dan gaya anak yang berbeda sesuai tingkat kematangan,perkembangan dan perbedaan latar belakangnya. (Nurwati, 2019). Model pembelajaran sentra mampu menstimulasi seluruh aspek kecerdasan anak ( multiple intellegensi) melalui bermain yang terarah (Fitriyah, 2008).

Multiple Intellegensi merupakan teori kecerdasan yang dikemukakan oleh Howard Gardner, seorang psikolog dari Harvard University, mengatakan setiap anak dilahirkan adalah cerdas. Kecerdasan tidak hanya terpaku di tingkat tertentu dan terbatas disaat anak lahir, bahwa "Setiap individu mengembangkan kecerdasan dengan bermacam cara yang dikenal dengan "multiple Intellegensi" (Yacub, 2013). Esensi teori kecerdasan jamak (multiple intellegences) menurut Gardner adalah berbagai variasi cara belajar, menghargai ciri atau karakter setiap orang, mewujudkan sejumlah model untuk menilai mereka dan cara yang hampir tak terbatas untuk mengekspresikan diri di dunia ini (Agustin, 2013). Adapun jenis kecerdasan yang bisa dikembangkan antara lain yaitu kecerdasan linguistik, kecerdasan matematis-logis, kecerdasan gambar dan ruang (visual-spasial), kecerdasan musical, kecerdasan kinestetik, kecerdasan interpersonal, kecerdasan intrapersonal, kecerdasan naturalis, dan kecerdasan eksistensi (Masdudi, 2017).

Perspektif multiple intelligence melalui pendekatan metode sentra mampu mengembangkan seluruh potensi anak didik melalui konsep bermain yang terarah dengan menggunakan media pembelajaran yang tepat sehingga terciptanya pola pembelajaran yang menyenangkan. Bermain merupakan hal yang sangat mendasar dalam proses belajar bagi anak untuk berfikir aktif dan kreatif, yang bertujuan untuk mengembangkan seluruh aspekaspek perkembangannya yang meliputi perkembangan nilai agama dan moral, fisik, kognitif, sosial emosional, bahasa dan seni. Belajar melalui bermain disetiap sentra juga mampu mengembangkan seluruh aspek kecerdasan anak didik secara optimal. 
http://jurnaltarbiyah.uinsu.ac.id/index.php/raudhah

Namun, fenomena masih banyak ditemukan di lembaga Pendidikan Anak Usia Dini (PAUD) maupun pengetahuan sebagai orang tua yang mayoritas masih belum memahami kemampuan anak secara luas, kemampuan tidak hanya diukur dari segi akademis saja melainkan kemampuan kognitif, psikomotorik, kemampuan afektif dan gaya belajar anak yang saling berkesinambungan sehingga kemampuan anak bisa terukur dengan baik dan tidak mempertimbangkan dalam pengembangan kecerdasan- kecerdasan yang lain (Multiple Intellegensi). Oleh karena itu peran orang tua/guru dalam memberikan pendidikan atau model pembelajaran harus tepat sehingga semua aspek perkembangan dan kecerdasan yang dimiliki anak mampu berkembang dengan baik.

Menurut hasil penelitian yang dilakukan pada tahun 2019 tentang penerapan model pembelajaran berbasis sentra dalam mengembangkan kecerdasan jamak (Multiple Intellegensi) setelah dilakukan analisis menunjukkan keberhasilan mampu mengembangkan kemampuan kecerdasan jamak anak usia dini, di setiap sentra anak-anak mampu mengeksplor kemampuan dirinya, belajar secara langsung dan nyata sehingga anak akan terdorong untuk belajar melalui bermain dengan menggunakan media yang menarik (Nurwati, 2019).

Hasil penelitian Mustajab dkk menyatakan bahwa kecerdasan majemuk (Multiple Intellegensi) sangat penting dilakukan pada anak usia dini sehingga diperlukan model pembelajaran yang tepat salah satunya melalui pendekatan sentra atau BCCT (Beyond Centre And Circle Time), diperlukan pengelolaan yang terencana, terstruktur dan sistematis. Melalui perencanaan, pelaksanaan dan evaluasi pembelajaran yang sistematik, multiple intelligences anak dapat dikembangkan dengan baik (Mustajab et al., 2021).

\section{B. METODE PENELITIAN}

Metode penelitian yang digunakan menggunakan menggunakan pendekatan kualitatif deskriptif.. Teknik pengumpulan data menggunakan observasi, melalui data kegiatan anak dan ruang sentra yang ada, wawancara dan dokumentasi Subyek penelitian ini terdiri dari Kepala Sekolah, Guru sentra kelompok B dan Anak didik yang berjumlah 15 anak di RA Azzahra Lampung Timur.Analisis data menggunakan model Miles Huberman terdiri atas mereduksi data, penyajian data dan penarik kesimpulan. Sedangkan untuk menguji keabsahan data dalam penelitian ini menggunakan triangulasi sumber dan teknik. 
http://jurnaltarbiyah.uinsu.ac.id/index.php/raudhah

\section{HASIL TEMUAN DAN PEMBAHASAN}

Berdasarkan hasil observasi yang peneliti lakukan dalam proses pembelajaran sentra dalam mengembangkan multiple intellegensi anak di RA Azzahra Lampung Timur meliputi, perencanaan, pelaksanaan dan Penilaian.

\section{Perencanaan pembelajaran sentra dalam mengembangkan multiple intellegensi anak}

Siti Aisyah (2021) sebagai kepala sekolah mengatakan bahwa sebelum pelaksanakan pembelajaran di setiap tahun ajaran baru, kepala sekolah bersama guru membuat perencanaan berupa Kurikulum Tingkat Satuan Pendidikan (KTSP) yang merencanakan program lembaga dan kurikulum yang akan dilaksanakan dengan mengacu pada kalender pendidikan yang ada, berupa Program Tahunan (PROTA), Program Semester (PROSEM), Rencana Kegiatan Mingguan (RKM) dan Rencana Kegiatan Harian (RKH) mengacu pada kurikulum 2013 yang disusun secara sistematis untuk mencapai keberhasilan dalam proses pembelajaran dan mendukung seluruh potensi anak didik.

\section{Implementasi pembelajaran sentra dalam mengembangkan multiple intellegensi anak}

Proses pembelajaran yang diterapkan di RA Azzahra Lampung Timur adalah belajar melalui bermain. Anak belajar dengan menyenangkan, belajar secara konkrit dan langsung mengalaminya. Sentra yang terdapat di RA Azzahra ada 5 sentra yaitu, sentra persiapan, sentra bahan alam, sentra seni, sentra balok dan sentra bermain peran.

Fatma Hernawati ( 2021) sebagai guru kelompok B di RA azzahra mengatakan bahwa kegiatan pembelajaran dalam satu minggu hanya dilaksanakan dari hari Senin- Jum'at mulai pukul. 07.30-11.00 WIB, dan setiap hari Sabtu libur. Adapun proses pelaksanaan pembelajaran yang dilakukan di RA Azzahra Lampung Timur melalui 7 tahapan diantaranya, kegiatan pembukaan, kegiatan sholat dhuha, kegiatan tahfidz, kegiatan motorik kasar (bermain di luar ruangan),istirahat/makan bersama, kegiatan inti/ sentra dan kegiatan penutup. Adapun proses kegiatan yang dilakukan adalah sebagai berikut :

Pertama, Kegiatan pembukaan. Kegiatan awal/pembukaan ini dimulai pukul 07.3007.45 WIB. Kegiatan yang dilakukan diantaranya; salam dari guru, greeting yang mencakup menanyakan kabar, bernyanyi lagu pembukaan dan lagu sesuai tema, dan berdoa bersama. Adapun doanya mencakup doa sebelum belajar, membaca dua kalimat syahadat, doa memohon kecerdasan, membaca surat Al-Fatihah, ikrar dan asmaul husna. Kegiatan selama pembukaan akan menstimulasi anak dalam meningkatkan multiple intelligences, yaitu Kecerdasan linguistik. Hal ini sejalan pendapat yang dikemukakan oleh Mubiar Agustin menjelaskan 
http://jurnaltarbiyah.uinsu.ac.id/index.php/raudhah

e-mail: jurnalraudhah@uinsu.ac.id

p-ISSN: $2338-2163$

e-ISSN: $2716-2435$

bahwa kecerdasan linguistik adalah potensi seseorang dalam menyampaikan kata- kata secara efektik baik tulisan maupun lisan (Agustin, 2013) .

Kedua, Kegiatan shalat Dhuha. Shalat Dhuha berjamaah dilakukan mulai pukul 07.4508.00 WIB. Sebelum melakukan sholat berjamaah anak anak melakukan wudhu bersama terlebih dahulu sesuai dengan Standar Operasional Prosedur (SOP) yang ditentukan seperti halnya; disiplin antri, do'a sebelum berwudhu, menggunakan air secukupnya, dan do'a setelah berwudhu dan dilanjutkan dengan sholat dhuha. Setelah melakukan sholat dhuha guru mengajak anak melakukan pembiasaan berdzikir bersama dengan membaca; istighfar, tasbih, tahmid, takbir, dan tahlil, doa kebaikan dunia akhirat dan do'a kedua orang tua.

Adapun perlengkapan yang digunakan seperti ruang kelas, mukena, peci, sajadah, imam dan makmum. Pada kegiatan shalat dhuha mengembangan kecerdasan dari sembilan kecerdasan, yaitu cerdas kinestetik dan cerdas bahasa (linguistik). Selanjutnya dijelaskan oleh Pertiwi (2014) kecerdasan kinestetik adalah kemampuan seseorang dalam mengkoordinasikan angota tubuhnya dalam berbagai gerakan yang berkesinambungan dengan kegiatan fisik seperti berlari,bergerak,berlari, dan berkomunikasi dengan menggunakan tubuhnya (Resa Respati, 2018).

Ketiga, kegiatan Tahfidz dan Qira'ati dilakukan mulai pukul 08.00- 08.30 WIB, kegiatan diawali dengan membaca do'a, dan muroja'ah surat-surat pendek yang dilakukan bersama-sama dilanjutkan belajar qira'ati secara individual dan bergantian dengan menghadap guru kelas masing-masing, Adapun alat yang digunakan ssesuai Standar Operasional Prosedur (SOP) buku iqra', buku prestasi, dan rekap nilai. Pada kegiatan Mentoring Tahfidz dan Qira'ati mengembangkan kecerdasan dari sembilan kecerdasan, yaitu cerdas bahasa (linguistik).

Keempat, kegiatan motorik kasar dilakukan mulai pukul 08.30-08.45 WIB, kegiatan motorik kasar dilakukan di luar ruangan dengan melibatkan semua anak di dalam kelompok dan guru sebagai pembimbing kegiatan tersebut seperti halnya bermain gerak dan lagu, tujuannya adalah menyiapkan mental anak (Ria Octa Viani, 2020). Kegiatan motorik kasar dari sembilan kecerdasan, yaitu cerdas kinestetik.

Kelima, Istirahat dan makan. Istirahat dan makan dilaksanakan mulai pukul 08.4509.15 WIB. Kegiatan istirahat dimulai dengan makan bersama dengan mematuhi SOP (Standar Operasional Prosedur) meliputi; disiplin antri cuci tangan sebelum makan ( wastafel, sabun,lap tangan), bekal makanan anak (bawa sendiri dari rumah) dan satu bulan sekali diberi bekal/makanan dari sekolah sebagai program pemberian makanan tambahan, serta perlengkapan makan dan minum. Dilanjutkan makan bersama dengan diawali berdoa, membaca doa setelah makan dan merapikan tempat makan, kegiatan setelah makan bermain 
http://jurnaltarbiyah.uinsu.ac.id/index.php/raudhah

e-mail: jurnalraudhah@uinsu.ac.id

p-ISSN: 2338-2163

e-ISSN: $2716-2435$

bebas outdoor. Kegiatan istirahat dan makan juga, mencakup kecerdasan dari sembilan kecerdasan, yaitu cerdas bahasa (linguistik) cerdas kinestetik.

Keenam, Kegiatan inti/sentra. Kegiatan inti/sentra berlangsung selama satu jam tiga puluh menit, yakni mulai pukul 09.15- 10.45 WIB oleh guru sentra pada masing-masing kelas sentra. Pembelajaran di dalam sentra dilaksanakan melalui empat pijakan, yaitu pijakan lingkungan main, pijakan sebelum main, pijakan saat main, dan pijakan sesudah main. Pijakan lingkungan main ialah penataan alat main yang akan digunakan (Setyowati, 2019), meliputi tempat main, jumlah jenis main, serta jumlah anak dalam satu kelas.

Pijakan sebelum main meliputi salam, doa, membahas/ tanya jawab tentang tema, menyebutkan aturan permainan meliputi; perhatikan, disiplin, bergantian, pilih teman, pilih mainan, mainkan, perlihatkan, merapikan alat main, sayang guru dan teman. Pijakan saat main meliputi mengamati (observasi), memotivasi dan menilai (Yennizar \& Hikmah, 2020). Anakanak berperan aktif menjadi pelaku utama dalam menyelesaikan permainan tersebut. Pijakan setelah main yaitu recalling, yakni penilaian dan review, menyanyi dan membaca doa sesudah belajar. Dari Sembilan kecerdasan yaitu cerdas interpersonal.

Dalam pelaksanaannya model pembelajaran sentra yang diterapkan di RA Azzahra setiap guru bertanggung jawab pada 15 ( lima belas ) anak secara moving class, sesuai dengan sentra gilirannya (Fauzia, 2020). Sentra yang dikembangkan terdapat lima sentra yaitu, sentra persiapan, sentra seni, sentra bahan alam, sentra balok, dan sentra bermain peran.

Adapun Rincian kegiatan sentra yang diterapkan di RA Azzahra Lampung Timur, dan hasil observasi pada bulan April 2021 Minggu II dengan Tema; Pohon-pohon Ajaib Ciptaan Allah, Sub Tema ; Buah-buahan, Topik : Buah Pisang. Adapun kegiatannya yang dilakukan disetiap sentra sebagai berikut :

Sentra Persiapan, di sentra persiapan terdapat tujuh ragam main, kegiatan yang dilakukan adalah; mendengarkan dan membaca cerita dengan buku, menyusun dan menempel kata pisang dengan menggunakan huruf potong, menuliskan kata "pisang, menyusun kata pisang dengan batu kerikil, menghitung jumlah pisang, stempel angka sesuai jumlah gambar pisang, puzzle gambar pisang. Kegiatan pra membaca dan berhitung dari Sembilan kecerdasan yaitu cerdas logis-matematis (Logical matematich), dan bahasa (linguistik). Sesuai yang dijelaskan oleh Mutiah bahwa kegiatan yang dilakukan dalam sentra persiapan ialah dalam tahap membaca, menulis dan berhitung permulaan (Rahmawati, 2019).

Sentra Bahan Alam, adapun di sentra bahan alam terdapat lima ragam main, yakni mengupas pisang, membuat sate pisang sesuai jumlah, observasi tanaman pisang ke kebun pisang yang ada di lingkungan rumah, mewarnai gambar pisang dengan kunyit,kolase gambar 
http://jurnaltarbiyah.uinsu.ac.id/index.php/raudhah

e-mail: jurnalraudhah@uinsu.ac.id

p-ISSN: 2338-2163

e-ISSN: $2716-2435$

pisang menggunakan daun pisang. Kegiatan di sentra bahan alam mencakup dari sembilan kecerdasan, yaitu kecerdasan naturalis. Pembelajaran di sentra bahan alam menekankan kegiatan pembelajaran yang memanfaatkan bahan-bahan alam yang ada dilingkungan sekitar dan salah satu cara yang dapat mengembangkan kecerdasan naturalis anak usia dini (Yunisari \& Amsal Amri, 2016).

Sentra seni, kegiatan di sentra seni terdapat empat ragam main, meliputi bernyayi, melukis kebun pisang, mewarnai gambar pisang, menggunting gambar pisang, kolase gambar dengan origami, finger painting kebun pisang. Aktivitas yang dilakukan di sentra seni mengajak anak untuk selalu dapat aktif dan kreatif dalam mewujudkan suatu karya yang dapat mengembangkan ide, gagasan, mengembangkan imajinasi/ kreativitas melalui metode proyek (Fitria et al., 2020). Disentra seni dari Sembilan kecerdasan, yakni cerdas music, cerdas gambar dan ruang (visual-spasial ).

Lebih lanjut, kegaiatan yang dilakukan di sentra balok terdapat dua jenis main, yakni membuat pola kebun buah menggunakan balok dilengkapi dengan asesosir buah dan menyusun kata pisang dengan balok. Sejalan yang dipaparkan oleh Saleh dan Wismiarti sentra balok adalah sentra yang dilengkapi berbagai macam balok bentuk geometri dengan berbagai ukuran dan tanpa warna, di sentra balok anak akan terstimulasi untuk menciptakan bentuk bangunan bervariasi yang terstruktur sesuai dengan ide atau gagasannya (Dhuriyatun Nasichah, 2017). Dari Sembilan kecerdasan kegiatan di sentra balok, yaitu cerdas gambar dan ruang (visualspasial ).

Terakhir, sentra bermain peran. Adapun kegiatan yang dilakukan adalah bermain peran makro (besar), anak berperan langsung sebagai model (Putri et al., 2019). Anak anak berperan dalam kegiatan jual beli buah-buahan dilengkapi dengan buah, dan perlengkapan jual beli. Kegiatan bermain peran dari sembilan kecerdasan, yakni cerdas bahasa (linguistik), cerdas interpersonal dan cerdas intrapersonal. Sesuai yang dijelaskan oleh Lilis Madyawati dalam bukunya, Strategi Pengembangan Bahasa pada Anak, manfaat dari bermain peran adalah : membangun kepercayaan diri pada anak, meningkatkan kreativitas dan akal, problem solving, memberi anak pandangan positif, mengembangkan kemampuan berbahasa, membangun kemampuan sosial dan empati, (Inten, 2017).

Ketujuh, Kegiatan penutup. Kegiatan penutup dilakukan pada pukul 10.45-11.00, meliputi refleksi kegiatan yang dilakukan dalam satu hari, bernyanyi dan tepuk, doa penutup majelis, janji pulang sekolah, mengingat pesan ibu guru, dan salam. 
http://jurnaltarbiyah.uinsu.ac.id/index.php/raudhah

e-mail: jurnalraudhah@uinsu.ac.id

p-ISSN: $2338-2163$

e-ISSN: $2716-2435$

\section{Evaluasi Pelaksanaan Pembelajaran Sentra dalam Mengembangkan Multiple Intellegensi Anak}

Selanjutnya, evaluasi dilakukan oleh guru dalam proses pembelajaran yang mengacu pada standar kurikulum 2013 dan sesuai dengan Standar Tingkat Pencapaikan Perkembangan Anak (STPPA) meliputi aspek nilai agama dan moral, bahasa, motorik, aspek sosial emosional dan kognitif . Adapun bentuk penilaian yang digunakan meliputi; observasi, catatan anekdot, ceklist dan portofolio. Evaluasi dan persiapan materi pembelajaran dilakukan dalam waktu seminggu sekali setiap hari sabtu yang bertujuan untuk mengetahui apakah proses pembelajaran setiap harinya mampu berjalan dengan baik atau belum sesuai standar yang disusun dan yang direncanakan.

\section{SIMPULAN}

Implementasi pembelajaran sentra dalam mengembangkan multiple intellegensi anak usia 5-6 tahun di RA Azzahra Lampung Timur menunjukkan hasil yang baik dengan dibuktikannya melalui kegiatan-kegiatan yang terstruktur meliputi perencanaan, pelaksanaan, dan evaluasi. Pelaksanaan pembelajaran sentra memberikan kesempatan kepada anak untuk memilih kegiatan sesuai minatnya, anak mampu mengeksplor kemampuan dirinya sehingga kecerdasan- kecerdasan anak akan muncul.

\section{DAFTAR PUSTAKA}

Agustin, M. (2013). MENGENALI DAN MENGEMBANGKAN POTENSI KECERDASAN JAMAK ANAK SEJAK DINI SEBAGAI TONGGAK AWAL MELAHIRKAN GENERASI EMAS. Cakrawala Dini, 4(2).

Akbar, E. (2020). Metode Belajar Anak Usia Dini. Kencana.

Ali Rochmad Noor. (2015). Analisis Konsep Howard Gardner Tentang Kecerdasan Majemkuk ( Multiple Intellegences) dan Implikasinya Terhadap Pembelajaran yang Sesuai Dengan Perkembangan Anak di TK Alam Alfa Kids Pati Tahun Ajaran 2014/2015. Universitas Islam Negeri Walisongo.

Dhuriyatun Nasichah, S. J. A. (2017). Implementasi Model Pembelajaran Sentra Balok Anak Kelompok B di TK Khadijah Pendegiling Surabaya. Jurnal PAUD Teratai, 6(3).

Fatmawati, L. (2019). Implementasi Model Pembelajaran Sentra di TK Amal Insani Yogyakarta. Golden Age Jurnal Ilmiah Tumbuh Kembang Anak Usia Dini, 4(2).

Fauzia, S. (2020). IMPLEMENTASI MODEL PEMBELAJARAN SENTRA DALAM PENANAMAN

Implementasi Model Pembelajaran Sentra untuk Mengembangkan Multiple Intellegensi Anak Usia Dini di RA Azzahra Lampung Timur 
http://jurnaltarbiyah.uinsu.ac.id/index.php/raudhah

e-mail: jurnalraudhah@uinsu.ac.id

p-ISSN: $2338-2163$

e-ISSN: 2716-2435

NILAI-NILAI AGAMA ISLAM ANAK USIA DINI DI TK AL KHODIJAH KEDUNGSOKO TULUNGAGUNG. IAIN Tulungagung.

Fitria, E., Rachmi, T., \& Prima, W. A. (2020). Penerapan Kegiatan Sentra Seni pada Pembelajaran di

PAUD. Ceria: Jurnal Program Studi Pendidikan Anak Usia Dini, 9(1). https://doi.org/10.31000/ceria.v12i1.2859

Fitriyah, A. (2008). Implementasi Model Pembelajaran Sentra Pada Pendidikan Agama Islam Dalam Menanamkan Keimanan Pada Anak Usia Dini di Taman Kanak-Kanak Al Falah Surabaya (Issue 1). UIN Sunan Ampel Surabaya.

Inten, D. N. (2017). Pengembangan Keterampilan Berkomunikasi Anak Usia Dini Melalui Metode Bermain Peran. Mediator: Jurnal Komunikasi, 10(1). https://doi.org/10.29313/mediator.v10i1.2712

Lailan, A. (2017). Model Pembelajaran Sentra Pendidikan Anak Usia Dini. An-Nahdhah, 2(10).

Mandasari, E. (2013). EVALUASI PENERAPAN MODEL PEMBELAJARAN BCCT SEBAGAI UPAYA PENINGKATAN MULTIPLE INTELLIGENCES PADA ANAK USIA 2- 4 TAHUN DI PAUD AZ- ZAHRAH SURABAYA. $J+P L U S$ UNESA, 2(1).

Masdudi, M. (2017). Konsep Pembelajaran Multiple Intelligences Bagi Anak Usia Dini. AWLADY: Jurnal Pendidikan Anak, 3(2). https://doi.org/10.24235/awlady.v3i2.1362

Mulyani, S. (2018). Model Pembelajaran Sentra di TK Al Irsyad Lemahabang Cirebon. Institut Agama Islam IAI Bunga Bangsa Cirebon.

Mustajab, M., Baharun, H., \& Iltiqoiyah, L. (2021). Manajemen Pembelajaran melalui Pendekatan BCCT dalam Meningkatkan Multiple intelligences Anak. Jurnal Obsesi : Jurnal Pendidikan Anak Usia Dini, 5(2). https://doi.org/10.31004/obsesi.v5i2.781

Mutiah, D. (2012). Psikologi Bermain Anak Usia Dini. Kencana Predana.

Nurwati. (2019). Penerapan Model Pembelajaran Berbasis Sentra dalam Mengembangkan Kecerdasan Jamak di Taman Kanak-Kanak Kota Samarinda. Southeast Asian Journal of Islamic Education, 2(1). https://doi.org/10.21093/sajie.v2i1.1860

Putri, M., Rakimahwati, R., \& Zulminiati, Z. (2019). Efektivitas Penerapan Metode Bermain Peran Makro terhadap Perkembangan Bahasa Lisan Anak di Taman Kanak-kanak Darul Falah Kota Padang. Jurnal Ilmiah POTENSIA, 4(1). https://doi.org/10.33369/jip.4.1.49-58

Rahmawati, D. (2019). PENERAPAN PEMBELAJARAN SENTRA PERSIAPAN DI TK ABA AL 
http://jurnaltarbiyah.uinsu.ac.id/index.php/raudhah

e-mail: jurnalraudhah@uinsu.ac.id

p-ISSN: $2338-2163$

e-ISSN: $2716-2435$

WAFA YOGYAKARTA. Universitas Ahmad Dahlan.

Resa Respati, L. N. T. R. (2018). GERAK DAN LAGU SEBAGAI MODEL STIMULASI PENGEMBANGAN KECERDASAN KINESTETIK ANAK USIA DINI. Jurnal Pendidikan Usia DIni, 12(2). https://doi.org/https://doi.org/10.21009/JPUD.122.13

Ria Octa Viani, J. (2020). PEMBELAJARAN GERAK DAN LAGU UNTUK MENINGKATKAN KECERDASAN KINESTETIK ANAK USIA DINI. Jurnal Anak Usia Dini Dan Pendidikan Anak Usia Dini, 6(2).

Setyowati, R. (2019). IMPLEMENTASI PIJAKAN PADA SENTRA BALOK DI TK ISLAM KANITA TIARA BAKI SUKOHARJO TAHUN AJARAN 2018 / 2019. Universitas Muhammadiyah Surakarta.

Yacub, J. (2013). Meningkatkan Prestasi Akademik. Darussalam Press.

Yennizar, N., \& Hikmah, M. (2020). Implementasi Pijakan Lingkungan Main pada Pembelajaran Sentra Persiapan di Taman Kanak- Kanak Mamba' ul Ulum Bajubang Kabupaten Batang Hari Jambi. Journal Of Islmaic Early Childhood Education Kindergarten, 3(2).

Yunisari, D., \& Amsal Amri, F. (2016). Pengembangan Kecerdasan Naturalis Anak Di Sentra Bahan Alam Pada Paud Terpadu Dharma Wanita Kota Jantho Kabupaten Aceh Besar. Jurnal Ilmiah Mahasiswa Pendidikan Anak Usia Dini, 1(1).

Implementasi Model Pembelajaran Sentra untuk Mengembangkan Multiple Intellegensi Anak Usia Dini di RA Azzahra Lampung Timur 